\title{
"Public-private partnership as an effective mechanism for attracting private investment in achieving the aims the socio-economic development of Ukraine"
}

\begin{tabular}{|c|c|}
\hline \multirow{5}{*}{ AUTHORS } & Yuliia Komarynska (D https://orcid.org/0000-0002-1747-1816 \\
\hline & Olha Kryshevych (D https://orcid.org/0000-0001-6136-8106 \\
\hline & Nataliya Linnyk (D) https://orcid.org/0000-0003-0705-2922 \\
\hline & Vladyslav Karelin (D https://orcid.org/0000-0002-6271-2447 \\
\hline & Olena Kofanova (D https://orcid.org/0000-0002-0919-7570 \\
\hline ARTICLE INFO & $\begin{array}{l}\text { Yuliia Komarynska, Olha Kryshevych, Nataliya Linnyk, Vladyslav Karelin and } \\
\text { Olena Kofanova (2019). Public-private partnership as an effective mechanism for } \\
\text { attracting private investment in achieving the aims the socio-economic } \\
\text { development of Ukraine. Problems and Perspectives in Management, 17(4), 469- } \\
\text { 479. doi:10.21511/ppm.17(4).2019.38 }\end{array}$ \\
\hline DOI & http://dx.doi.org/10.21511/ppm.17(4).2019.38 \\
\hline RELEASED ON & Thursday, 09 January 2020 \\
\hline RECEIVED ON & Wednesday, 25 September 2019 \\
\hline \multirow[t]{2}{*}{ ACCEPTED ON } & Wednesday, 25 December 2019 \\
\hline & 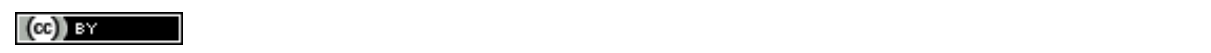 \\
\hline LICENSE & $\begin{array}{l}\text { This work is licensed under a Creative Commons Attribution } 4.0 \text { International } \\
\text { License }\end{array}$ \\
\hline JOURNAL & "Problems and Perspectives in Management" \\
\hline ISSN PRINT & $1727-7051$ \\
\hline ISSN ONLINE & $1810-5467$ \\
\hline PUBLISHER & LLC "Consulting Publishing Company "Business Perspectives" \\
\hline FOUNDER & LLC "Consulting Publishing Company "Business Perspectives" \\
\hline
\end{tabular}

NUMBER OF REFERENCES

28
NUMBER OF FIGURES

7
$-=-$
$z=-$

NUMBER OF TABLES

3

(C) The author(s) 2022. This publication is an open access article. 


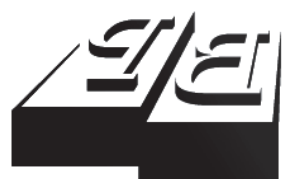

BUSINESS PERSPECTIVES

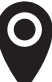

LLC "CPC "Business Perspectives" Hryhorii Skovoroda lane, 10, Sumy, 40022, Ukraine

www.businessperspectives.org

Received on: $25^{\text {th }}$ of September, 2019 Accepted on: $25^{\text {th }}$ of December, 2019

(C) Yuliia Komarynska,

Olha Kryshevych, Nataliya Linnyk, Vladyslav Karelin, Olena Kofanova, 2019

Yuliia Komarynska, Ph.D. in Juridical Sciences, Associate Professor,

National Academy of Internal Affairs, Ukraine.

Olha Kryshevych, Ph.D. in Juridical Sciences, Associate Professor,

National Academy of Internal Affairs, Ukraine.

Nataliya Linnyk, Ph.D. in Juridical Sciences, Kyiv University of Law of the National Academy of Sciences of Ukraine, Ukraine.

Vladyslav Karelin, Ph.D. in Juridical Sciences, Academy of State Penitentiary Service, Ukraine.

Olena Kofanova, Ph.D. in Juridical Sciences, Associate Professor, National Academy of Internal Affairs, Ukraine.

\section{(ㄷ) (i)}

This is an Open Access article, distributed under the terms of the Creative Commons Attribution 4.0 International license, which permits unrestricted re-use, distribution, and reproduction in any medium, provided the original work is properly cited.

Yuliia Komarynska (Ukraine), Olha Kryshevych (Ukraine), Nataliya Linnyk (Ukraine), Vladyslav Karelin (Ukraine), Olena Kofanova (Ukraine)

\title{
PUBLIC-PRIVATE PARTNERSHIP
} AS AN EFFECTIVE MECHANISM FOR ATTRACTING PRIVATE INVESTMENT IN ACHIEVING THE AIMS THE SOCIO-ECONOMIC DEVELOPMENT OF UKRAINE

\begin{abstract}
The article analyzes public-private partnership (PPP) as a form of interaction between state and business in the context of optimizing the Ukrainian economy. According to the results of SWOT analysis of the implementation of PPP projects in the infrastructure of Ukraine (2017-2019), the main criteria that determine the necessary model of public-private partnership were substaintiated, namely the distribution of investments, risks, obligations between the state and the private sector, the term and object of the agreement.

The study analyzed the impact of economic, political, legislative and criminal processes on public-private partnerships in Ukraine. It was proved that the formation of specific allocation relations based on the interaction between public and private property is the most important feature of public-private partnership, which distinguishes it from other forms of interaction between the state and business. Advantages of PPP are as follows: the increase of management efficiency of state and municipal property objects, the reduction of tax burden on the state budget and optimization of budget expenditures on public services provision, the maintenance of budget-funded institutions, etc. It has been established that the PPP is the best alternative to privatization in order to attract private investment in strategic infrastructure facilities.
\end{abstract}

\section{Keywords}

\section{JEL Classification L L32, L33}

\section{INTRODUCTION}

Nowadays, the practice of using different forms of partnership between the state and private business in different sectors of national economies is becoming more and more widespread. Such partnership contributes to the activation of the investment orientation of the economy, ensuring long-term socio-economic growth.

Over the past few years, public-private partnership in Ukraine has become increasingly important, because attracting investment, developing national, regional and local infrastructure, expanding and providing better services to citizens are priorities for the state. It is also evident, that ensuring a high and stable rate of development of both country and its regions is impossible without the effective partnership of state and/or local authorities with representatives of private business. Strategies and programs that focus solely on the use of budget funds do not allow authorities to implement large-scale, strategic pro- 
jects that shape the country's competitiveness. The world-renowned alternative to this type of financing is public-private partnership.

Implementation of large infrastructure projects in various sectors of the economy requires significant investment resources, which can be a powerful source of private business. At the same time, business interest in state support increases, which will reduce the risks of private investment, increase the reliability of investment projects for credit institutions, including the ones at the local level.

Public-private partnership as a component of the economic institute of contemporary social development, its various forms have great potential for achieving the general goals of sustainable development of the country based on the consolidation of state assets with investment, management and other resources of the private sector.

\section{THEORETICAL BASIS}

Public-private partnership as an economic concept was formed in the late 90s. Since then, the term "public-private partnership" (hereinafter PPP) remains unchanged, which can not be said about the theoretical and methodological elucidation of the essence of this public institution. It is constantly changing, improving, due to the deep nature of the PPP as a practice of interaction between the state and business to achieve the overall goals of socio-economic development of countries (Kredisov \& Bilous, 2016).

The essence of the PPP is an institutional and organizational unity of government and private business to implement socially important projects in a wide range of fields of activity, from developing the strategically important sectors of the country's economy to providing the public services, both for the country as a whole and for individual territories (K. Pavlyuk \& S. Pavlyuk, 2010).
According to Danylyshyn (n.d.), the PPP mechanism, as one of the forms of interaction between the state and the private sector of the economy, offers better opportunities to obtain the desired level of efficiency in the implementation of largescale projects important for the whole country.

The term "public-private partnership" in most foreign countries is used to determine the existing forms of cooperation between the state and other economic entities. A critical analysis of existing scientific views has shown that the definition of PPPs among both domestic and foreign scientists contains significant differences (Uzunov, 2015; Laptiy, 2017; Filyppowa \& Malin, 2017).

The partnership is carried out between the institutions of the state at all levels of government, the private sector, which includes investors and business organizations, and civil society representatives to address the socially important issues that are relevant to the competence of the state and to

Source: Compiled based on the analysis of legislative acts regulating public-private partnership issues.

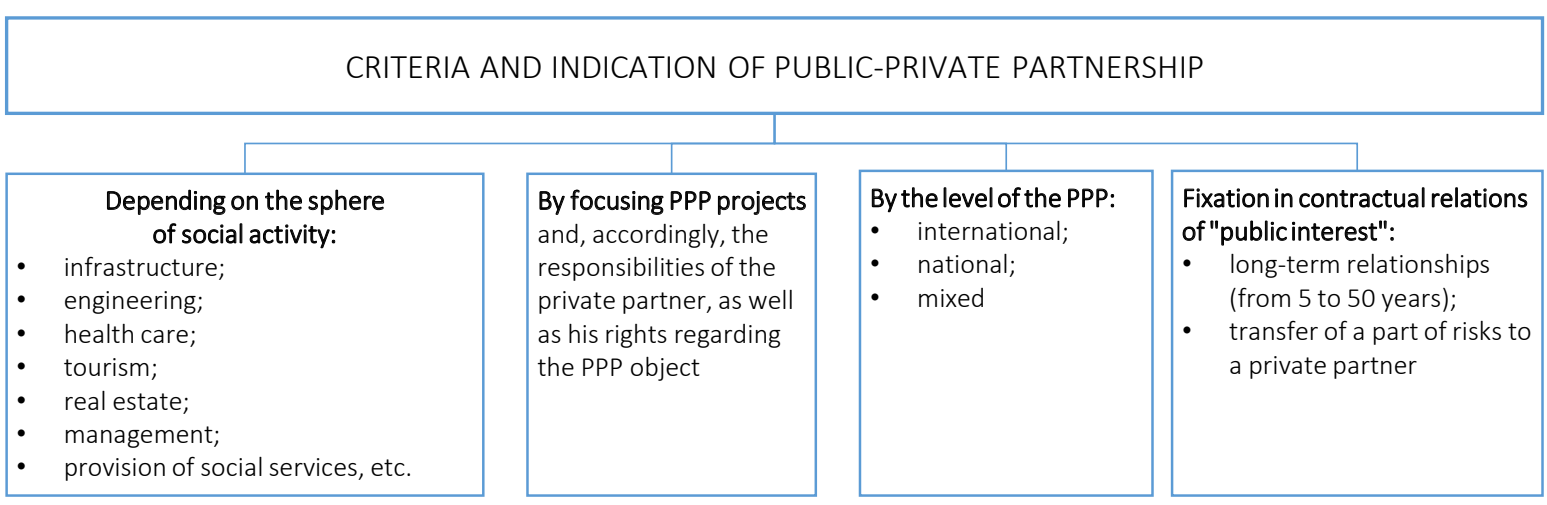

Figure 1. Public-private partnership criteria 


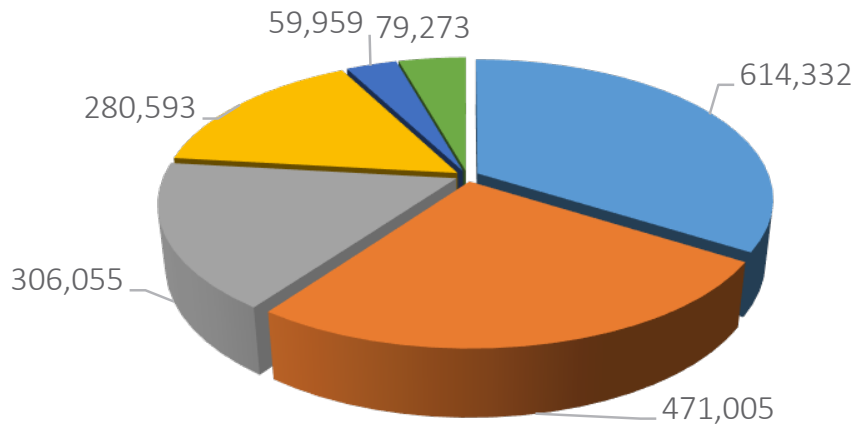

\author{
- Caribbean countries, Latin America \\ - East Asia countries \\ South Asia countries \\ - Central Asia countries and Europe \\ North Africa and M. East \\ - Sub-Saharan Africa
}

Figure 2. Regions, ranked by number of projects (1991-2019) (USD million)

obtain mutual economic benefits. The state partner focuses on the adoption of necessary regulatory acts, the definition of goals and objectives of PPP projects, quality of services, pricing policies, monitoring of project implementation, that is, it performs regulatory and coordinating functions (Varnavsky, Klymenko, \& Korolev, 2010).

The issues of PPP in Ukraine are regulated by the Laws of Ukraine "About Public-Private Partnership," "About Concessions," three other laws and separate articles of the Civil and Commercial Codes of Ukraine, as well as 18 by-laws.

The study of the dynamics of private equity participation in investment projects according to the World Bank is characterized as follows (see Figure 2).

Analyzing the experience of developed countries of the world, such as France, Germany, Austria, Italy, Brazil, where public-private partnership is seen as a prerequisite for the development of an efficient market economy, it should be noted that the most active in these countries is the form of public-private partnership as a concession. Such partnerships are effective in the social sphere (education, tourism, health care, etc.), municipal infrastructure (water and sanitation, etc.) and transport infrastructure (highways, airports, etc.). At the same time, the transport infrastructure takes the leading position, further - social infrastructure (Pavlova, 2011).

The interaction between business and government is an important indicator of the state of society as a whole. The relationship between them affects the nature of power, style, and technology management.

According to the UN Summit Outcome "The Transformation of our World: An Agenda for Sustainable Development to 2030," which approved 17 Sustainable Development Goals and 169 Objectives, the Government of Ukraine has elaborated the National Report "Sustainable

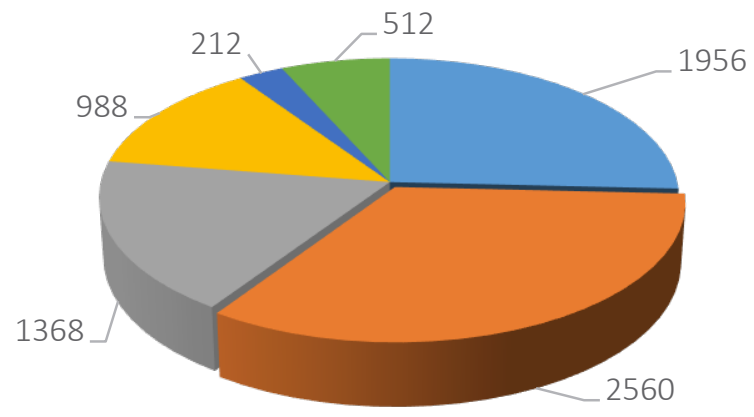

Source: The World Bank.

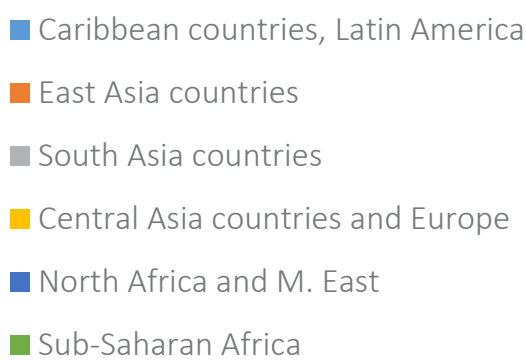

Figure 3. Regions ranked by investment (1991-2019). 
Development Goals: Ukraine," which provides a vision of the landmarks the achievement by Ukraine of the Objectives of Sustainable Development (OSD), which defines the basic indicators for the achievement of the OSD in our country, following the adaptation of 17 global OSDs, considering the specifics of national development. Among the tasks identified by Ukraine in the long run are extremely ambitious and complex, in particular to reduce the energy intensity of GDP by 2 times; to provide an increase in the rating of Ukraine in the ease of doing business, rising from 81 to 20 place; 5 times increase the cost of performing scientific and scientific and technical works, as well as more than 10 times - the share of realized innovative products in the volume of industrial; to increase the net inflow of foreign investments by almost 6 times; increase the number of projects implemented under the conditions of public-private partnership to 45 . The achievement of the OSD requires the partnership of state bodies, the private sector, civil society, and citizens (Reports from the National Report "Sustainable Development Goals: Ukraine,” 2017).

One of the important tendencies in the development of the PPP after the approval of the OSD was the transformation of the traditional PPP model into a model compatible with the SDD, which was called "human-oriented PPP." This new type of PPP is positioned as a mechanism for achieving the sustainable economic and social development through PPP programs with a focus on its role in ensuring the social equality and sustainable development. The priority of people brings the principles of work and the aims of the PPP model to a new level (Reports from the National Report "Sustainable Development Goals: Ukraine," 2017; First session of the Working Party on PublicPrivate Partnerships, 2017). The characteristic of this model lies in its orientation towards a wider spectrum of criteria for those who create "value for people," rather than simply based on the value of money.

Creation, maintenance, and development of objects of national and regional importance in Ukraine (such as energy, development and extraction of minerals, construction of transport infrastructure, introduction of family medicine system, various socio-cultural projects) are lagging behind the world by their standards.

The most important resource, which is lacking in solving the problem, is the means. Public funding only partially covers the need for them. One of the options for resolving this issue is the implementation of the PPP, which has already become customary in Western Europe and other countries of the world (Kredisov \& Bilous, 2016). However, in Ukraine, the high level of corruption has a negative impact on these processes.

In 2018, Ukraine took the 120-th (Table 1) place out of 180 countries, which were explored, in the Corruption Perception Index of an international organization Transparency International (Yurtayeva, 2018; Borovik, 2019), progress in 10 places per year.

According to the Ministry of Internal Affairs of Ukraine, from 2014 to 2018, 15.8 thousand bribe takers were exposed. The overall trend of bribery outcomes has improved slightly, both in the number of bribery cases discovered $(+7 \%$ in 2018 versus 2014) and in the share of bribery in the total number of offenses in the field of official activity (15\% in 2014 against 18\% in 2018). In 2018 alone, 179 bribes were disclosed, the sum of which exceeded 100 thousand UAH (585 in the five years in total). The number of bribes over UAH 250,000 increased in 2018 compared to 2014 (Reports from the Ministry of Internal Affairs of Ukraine, 2014-2018).

Table 1. Indexes of Ukraine in the World Corruption Perception Rating

Source: https://www.transparency.org/cpi2018

\begin{tabular}{c|c|c|c|c|c|c}
\hline Year & Rank & CPI score & $\begin{array}{c}\text { Number of } \\
\text { sources }\end{array}$ & $\begin{array}{c}\text { Standard } \\
\text { error }\end{array}$ & $\begin{array}{c}\text { Bertelsmann Foundation } \\
\text { Transformation Index }\end{array}$ & $\begin{array}{c}\text { World Justice Project } \\
\text { Rule of Law Index }\end{array}$ \\
\hline 2018 & 120 & 32 & 9 & 2.27 & 41 & 36 \\
\hline 2017 & 130 & 30 & 9 & 2.27 & - & - \\
\hline 2016 & - & 29 & 9 & 1.97 & - & - \\
\hline 2015 & - & 27 & 8 & 1.93 & - & - \\
\hline
\end{tabular}


The national economy has traditionally been characterized by an unfavorable business climate, which creates the obstacles to the development of the private sector. Although economic crime in 2018 has increased by almost 300\% compared to 1992 (Kofanova, Tereshchenko, Kutsyi, Morhun, \& Gushchyn, 2019), and the results of international rankings, including "Doing Business - 2018" and "Global Competitiveness Index 2018-2019," show that the business climate in Ukraine is worse than in the neighboring countries. At the same time, the results of these ratings prove that the situation has improved rapidly in recent years. In particular, in the Doing Business 2018 ranking published by the World Bank, Ukraine has risen from 152 place in 2012 to 71 place in 2019 (Bogatyrev, Topchiy, Koropatnik, Kotliarenko, \& Kofanov, 2019). Such dynamics indicates that Ukraine has its significant potential and is actively pursuing reforms, but the business climate needs to be improved.

An important subject of the study is the position of Ukraine to take into account the World Bank's recommendation on the Public Expenditure and Financial Actuation (PEFA) and the related assessment tool of the public finance management efficiency assessment system for public investment management to take into account similar features between management state investments and PPP given the need to ensure their coordination within the framework of an interconnected system of budget planning (The World Bank, 2015).

These are two unconditionally related processes. Both support the creation of infrastructure and provide services that are characterized by a significant component of the public good, or consider market imperfections that impede the provision of these services by the private sector. Both provide for public sector financial liabilities, including direct and/or contingent liabilities. However, the management of these processes is often carried out separately, negatively affecting the proper selection of projects, preventing the effective use of inadequate public resources, creating unnecessary financial risks, and thus undermining financial stability.

The PPP product in the context of public investment management aims to create a detailed evaluation tool that covers the entire investment cycle, from policy and from pre-evaluation to factual verification based on a unified approach to the effectiveness of the management of traditional government investment and PPP.

The analysis of the opinions of scientists and researchers on the essence and content of public-private partnership and its comparison with the essence and content of public-private partnership gives grounds to conclude that public-private partnership is a system of relations between the state and business that should be considered as a kind of European public-private partnership. The meaningful use of these concepts depends on the model and culture of public administration, the level of socio-economic development of the country, the business climate, and the provision of invariant security (Mashchenko, 2018) of any country.

Public-private partnerships are one of the tools to attract additional investment resources in the public sector of the economy and promote the development of state-business partnerships. In the complex conditions of the Ukrainian economy, PPP and People-First PPPs are an actual form of cooperation between public and private partners, an urgent requirement not only for profit but also for social responsibility to society. The implementation of the PPP mechanism will contribute to the implementation of the state policy of Ukraine, oriented to international standards and clearly aimed at increasing social standards of living, economic growth, and the achievement of sustainable development of the country.

\section{RESULTS}

The study of the state of the economy of Ukraine in 2018 and 2019 (I quarter) indicates that the real gross domestic product (GDP) in 2019 (I quarter) compared with 2018 (IV quarter) increased by $0.3 \%$, and compared with 2018 (I quarter) - by $2.5 \%$. Nominal GDP amounted to 807.8 billion UAH, and GDP per person - 19,179 UAH (Reports from the State Statistics Service of Ukraine).

According to the latest World Bank Economic Survey for Ukraine, in 2018, the economy grew by $3.3 \%$. Nevertheless, investors' confidence is re- 
Source: State Statistics Service of Ukraine. Real GDP, taking into account the seasonal factor (I quarter 2019 to IV quarter 2018) increased by $0.3 \%$. Nominal GDP in I quarter 2019 - UAH 807.8 billion

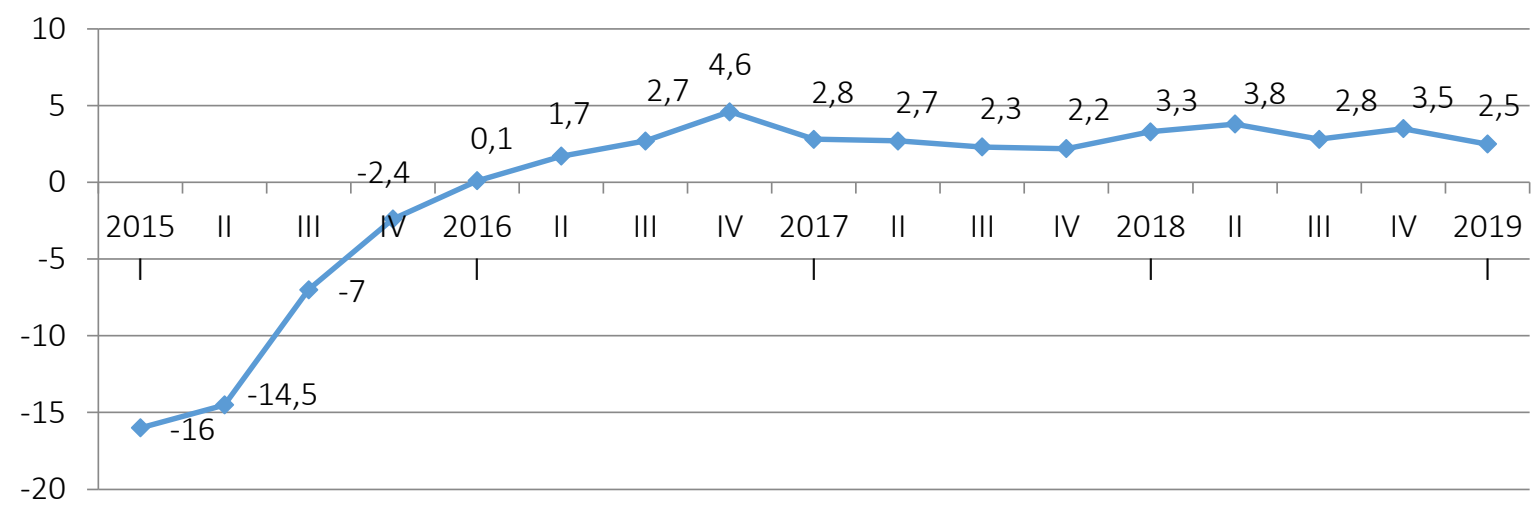

—Change in real GDP (in \% to the corresponding quarter of the previous year)

Figure 4. Changes in real GDP according to the State Statistics Service of Ukraine

strained by uneven progress in implementing the reforms, election-related uncertainty, and high borrowing costs. Moreover, in 2019, the economy is projected to grow at $2.5 \%$. If key reforms are to go forward, economic growth is expected to reach $3.4 \%$ in 2020 and $3.8 \%$ in 2021 . Otherwise, in the case of delayed reforms, economic growth may slow down to below $2 \%$, as investor confidence worsens and macroeconomic vulnerability increases (data of Ukrainian authorities, World Bank projections).

According to a special report from the World Bank entitled “Implementing Ukraine's Economic Growth Potential" as of May 23, 2019, achieving a high level of economic growth will require a combination of increased productivity and investment. Investment support and productivity growth will require policy reform in three areas:

- reducing the role of the state in the economy, removing the obstacles to the use of factors of production and strengthening the human capital to create the impetus for productivity growth;

- promoting FDI and integrating into global value chains, improving the logistics and communications to maximize the potential of foreign trade. One of the most important factors in attracting FDI is the protection of property rights;

- maintaining a stable macroeconomic policy, providing everyone with equal opportunities, and strengthening the rule of law to make economic institutions more sustainable.
Table 2. Acquisition of capital investments in\% in the ratio from January-March 2019 to JanuaryMarch 2018

Source: State Statistics Service of Ukraine.

Capital investments ( $\Delta \mathbf{1 1 7 . 8 \% )}$

From January-March 2019 to January-March 2018, \%

\begin{tabular}{l|l}
\hline Kherson & 236.3
\end{tabular}

Volyn, Ternopil, Kyiv, Poltava, Dnipropetrovsk $\quad 131.0-166.9$

Luhansk, Kharkiv, Sumy, Odesa, Mykolaiv, Vinnytsia, Lviv, Chernivtsi

$104.2-128.7$

Ivano-Frankivsk, Zakarpattia, Rivne, Zhytomyr,

Khmelnytskyi, Chernihiv, Cherkasy, Kirovohrad,

Donetsk, Zaporizhzhia

$70.1-97.1$

Cyprus (25.6\%) is among 121 countries that invest in the Ukrainian economy. The Netherlands, Germany, France, Austria, Luxembourg, and the United Kingdom, which are members of the European Union, also make a significant contribution to the country's economy (Reports from the State Statistics Committee of Ukraine 20162018; Bogatyrev et al., 2019).

At the beginning of 2017, the industry is the largest sector of the economy of Ukraine in terms of attracting the investments. Significant investments are also observed in financial and insurance activities $(26.4 \%)$, as well as in wholesale and retail trade (13.3\%) (Reports from the State Statistics Committee of Ukraine 2016-2018; Bogatyrev et al., 2019).

The main features of Ukraine's development in 2016-2018 were the gradual overcoming of manifestations of negative processes of economic 


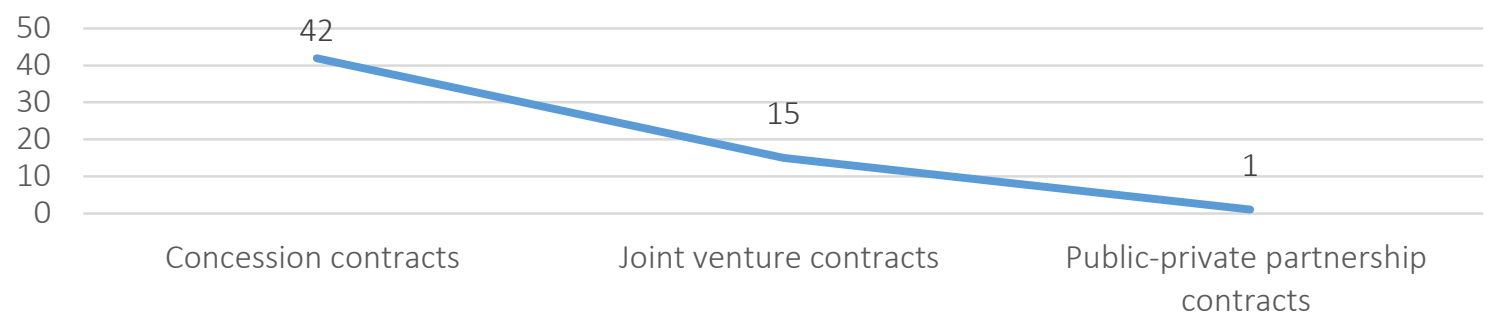

Figure 5. Contracts being implemented

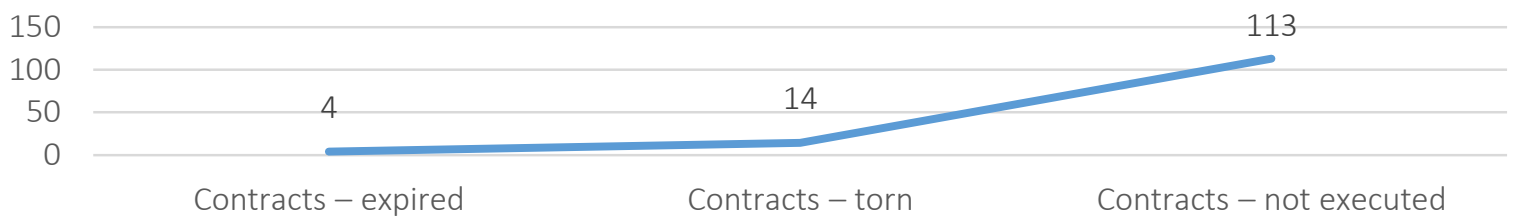

Figure 6. Contracts not implemented

development and laying the basis for sustainable economic growth. Over the past three years, Ukraine's total GDP growth amounted to $8.4 \%$, which means that for 13 quarters of a row, the economy has been growing steadily in the context of a significant change in the political landscape, political turbulence, and this despite the fact that Ukraine annually sends more than 5\% of GDP or 6 billion US dollars on security and defense in connection with the continuation of the actual war in the East. Thanks to the initiated systemic reforms in the economic block, the shadow economy has been reduced to $30 \%$ of GDP, which is 10 percentage points lower than in 2015. Inflation stalled at 8.8\% in April 2019 with a steady increase in wages. The growth rate of average wages in the economy exceeds the rate of increase of the minimum wage, which indicates the existing opportunities in the economy to raise wages and is conditioned by the effort to maintain the labor potential in Ukraine.

In July 2019, in Toronto (Canada) at the international event "Innovation, Opportunities and Democracy in Ukraine," it was noted that, unlike the common perception, private shareholders, asset management companies, and real sector investors consider Ukraine as an attractive and predictable market, as it develops and hides large, qualitative, and measurable assets (Reports from the Ministry of Economic Development and Trade). The same position was expressed in January 2019 at the Ukraine House Davos and the Norwegian-Ukrainian Business Forum in
Oslo on the availability of high-quality assets that are underestimated in the world market and this increase the attractiveness of Ukraine as an investment environment (UkraineInvest, 2019).

According to the data of central and local executive bodies in Ukraine, as of January 1, 2019, 189 contracts were concluded based on the PPP.

Areas of public-private partnership use are shown in Table 3.

In world practice, public-private partnerships are aimed at attracting private investments (both for their country and foreign ones) on long-term conditions for financing and management of public infrastructure. For Ukraine, there are three ways of implementing the investment projects - traditional state investment, public-private partnership and concessions (Zapatrina, 2016). Practice shows that according to the criterion of the level of PPP in Ukraine, both large national infrastructure projects and local level projects are being implemented.

Analyzing the strengths and weaknesses for the successful implementation of PPP projects in Ukraine (SWOT-analysis), as a strength it should be noted the advantageous geographical location and significant transit potential.

The implementation of public-private partnership projects allows for system investments in the transport, port, and Internet infrastructure of Ukraine. 
Table 3. The state of PPP implementation in Ukraine

Source: Ministry for Development of Economy, Trade and Agriculture of Ukraine (http://www.me.gov.ua).

\begin{tabular}{|c|c|c|c|c|c|c|c|c|c|c|c|c|c|c|c|c|}
\hline $\begin{array}{l}\text { Project areas of } \\
\text { application }\end{array}$ & 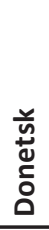 & 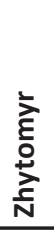 & 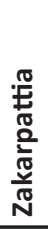 & $\begin{array}{l}\frac{\pi}{\frac{\pi}{N}} \\
\frac{\mathbf{N}}{N} \\
\frac{N}{2} \\
\frac{0}{0} \\
\frac{0}{N}\end{array}$ & 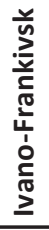 & $\gtreqless$ & 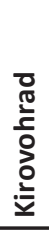 & 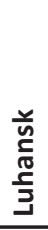 & i & $\frac{\frac{\lambda}{\pi}}{\frac{y}{0}}$ & 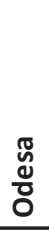 & 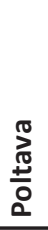 & 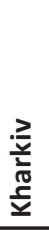 & 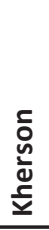 & 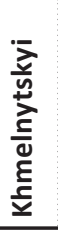 & \\
\hline $\begin{array}{l}\text { Prospecting, mineral } \\
\text { exploration }\end{array}$ & 1 & - & - & - & - & - & - & - & - & - & - & - & - & - & - & - \\
\hline Infrastructure & - & - & - & - & 1 & - & - & - & - & - & 5 & - & - & 1 & - & - \\
\hline Waste heap & 1 & - & - & - & - & - & - & - & - & - & - & - & - & - & - & - \\
\hline Real estate management & - & - & - & - & - & - & - & - & 2 & - & - & - & - & - & - & - \\
\hline $\begin{array}{l}\text { Natural gas production/ } \\
\text { transportation }\end{array}$ & 2 & 1 & 3 & - & - & 4 & - & - & 1 & - & - & - & - & - & - & 1 \\
\hline $\begin{array}{l}\text { Water collection, } \\
\text { purification and distribution }\end{array}$ & - & - & 1 & 3 & - & 4 & - & 1 & 1 & 14 & - & 1 & - & - & - & - \\
\hline Tourism & - & - & - & - & - & - & 1 & - & - & - & - & - & - & - & - & - \\
\hline Electricity production & - & - & - & - & - & 1 & - & - & - & 1 & - & - & 1 & 1 & - & - \\
\hline Other & 1 & - & - & 1 & - & 1 & - & - & - & - & - & - & - & - & 2 & - \\
\hline
\end{tabular}

Till the preparation of conclusions on PPP projects, Ministry of Finance, Ministry of Economic Development and Trade, Ministry of Infrastructure, Ministry of Energy and Coal Industry of Ukraine. To date, conclusions have been prepared based on the results of the analysis of the effectiveness of the implementation of the PPP:

- project "Energy Bridge" Ukraine-European Union";

- project "Reconstruction of the existing and creation of a new cargo terminal at Boryspil airport";

- project "Fuel and refueling complex at Boryspil International Airport";

- concession project at the Specialized Seaport of Olbia;
- concession project in the Kherson seaport (Reports from the Ministry of Economic Development and Trade).

During 2017-2019, there is a positive trend for the regional application of the PPP mechanism.

Most projects are implemented in such areas of economic activity as collection, treatment and distribution of water and production, transportation and heat supply, respectively, $47 \%$ (31 projects) and $12.1 \%$ (8 projects) of the total number of projects. The most common form of PPP is a concession (62\% of the total number of contracts). At the regional level, competitions are conducted to select a private partner for the implementation of PPP.

Analysis of the practice of applying public-private partnerships (PPPs) models suggests that each PPP agreement should be developed taking into ac-

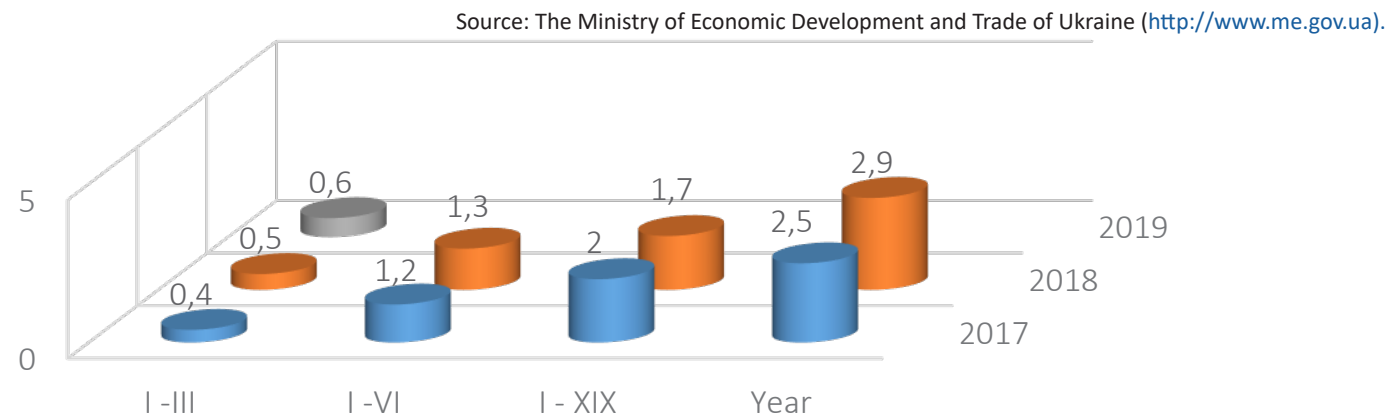

Figure 7. Acquisition of direct investment in Ukraine (USD billon) 
count the specific characteristics of the assets and capabilities of all partners involved in the project (Renda \& Schrefler, 2005). In order to guarantee a correlation between price and quality, strengths and weaknesses, the shortcomings of each PPP scheme should be carefully analyzed. Depending on the economic sector, some PPP models are better suited than others in achieving targeted results and in providing accurate risk management. Choosing the wrong model or misjudging the risk management capabilities of each side can have very costly consequences.

Ukraine has signed a Memorandum with the International Finance Corporation (IFC) of the World Bank Group in order to improve the procedures and ensure the social responsibility of PPP participants in order to attract international experts and international experience to work on PPP projects. This document will provide expert support to consultants from the International Finance Corporation to start the work of the Agency for Public-Private Partnership Support in Ukraine (PPP Agency). The main functions of the Ukrainian Agency will be identification of PPP projects, preparation of feasibility studies for state partners, assistance in preparing competitive documentation, conducting trainings and conferences, etc. All this will contribute to the implementation of quality and investment-attractive projects in the transport, municipal, energy, social, and other fields that will be beneficial for investors, the economy and society of Ukraine (Reports from the Ministry of Economic Development and Trade).

\section{CONCLUSION}

According to the results of SWOT analysis of PPP projects in the infrastructure of Ukraine, this form of interaction is the best alternative to privatization in attracting private investment in the strategic infrastructure. Implementation of PPP projects requires a high level of state expertise and a responsible approach to project evaluation and control. The main criteria for determining the required PPP model are the distribution of investments, risks, obligations between the state and the private sector, the term and object of the transaction.

In the course of the study, it was determined that the formation of specifics of assignment of relations based on the interaction of forms of public and private property, as well as the involvement of business in all stages of the project and the long-term nature of cooperation, is the most important feature of PPP, which distinguishes it from other forms of interaction between the state and business. In addition, in the course of analysis of the peculiarities of development and the current state of public-private partnership in Ukraine, it was established that for the practical implementation of the main forms of PPP in order to attract private investment resources for the modernization of the Ukrainian economy, it is necessary to improve the legal framework and expand the law enforcement practice to initiate and manage the projects considering the contemporary crisis trends.

\section{REFERENCES}

1. Agazaryan, N. (2016). Analiz mirovogo opyta primeneniya mekhanizma gosudarstvennochastnogo partnerstva [Analysis of world experience in applying the mechanism of public-private partnership]. Gosudarstvenno-chastnoe partnerstvo - Public-private partnership, 3(2), 151-172. (In Russian). Retrieved from https:// creativeconomy.ru/lib/37071

2. Bogatyrev, I., Topchiy, V., Koropatnik, I., Kotliarenko, O.,
\& Kofanov, A. (2019). Problems and perspectives for attracting investments in economy of Ukraine. Investment Management and Financial Innovations, 16(2), 195 205. http://dx.doi.org/10.21511/ imfi.16(2).2019.17

3. Borovik, A. (2019). CPI-2018: Ukraina znovu hirshe vsikh susidiv, okrim Rossii [CPI-2018: Ukraine is again worse than all its neighbors, except Russia]. Transparency International Ukraine. (In Ukrai- nian). Retrieved from https://tiukraine.org/news/cpi-2018-ukrayina-znovu-girshe-vsih-okrim-rosiyi/

4. Danylyshyn, B. (n.d.). Derzhavnopryvatne partnerstvo - stratehichna forma vzaiemodii vlady i biznesu [Public-private partnership - a strategic form of interaction between government and business]. (In Ukrainian).

5. Economic Commission for Europe Committee on Innovation, Competitiveness and Public-Private 
Partnerships. (2017). Expert and consultancy advice in low income countries for drafting regulations and developing People first PPP projects meeting the Sustainable Development Goals (SDGs): A major issue deserving innovative approaches. Working Party on Public-Private Partnerships First session Geneva, 21-22 November 2017. Item 5 of the provisional agenda Draft Proposal for Guidelines on Transformative PPP Implementation and Sustainable Development. Retrieved from https://www.unece.org/fileadmin/ DAM/ceci/documents/2017/PPP/ WP/ECE_CECI_WP_PPP_2017_ INF.2.pdf

6. Economic Discussion Club. (2018). Doing Business-2018. Ukraina $v$ reytynhu Svitovoho Banku lehkosti vedenniia biznesu [Doing Business-2018. Ukraine in the ranking of the World Bank ease of doing business]. (In Ukrainian). Rertrieved from http://edclub. com.ua/analityka/doing-business2018-ukrayina-v-reytyngu-svitovogo-banku-legkosti-vedennyabiznesu

7. Filyppowa, S., \& Malin, O. (2017). Derzhavno-pryvatne partnerstvo: problemni pytannia ta stratehichni zavdannia v umovakh smartyzatsii innovatsiinoho rozvytku [Publicprivate partnership: problem issues and strategic tasks in terms of smart-innovation development]. Ekonomika: realii chasu - Economy: realities of time, 5(33), 5-15. (In Ukrainian). Retrieved from http://dspace.opu.ua/jspui/ handle/123456789/7572

8. Jomo, K., \& Chowdhury, A. (2009). Reconsidering publicprivate partnerships in developing countries. International Journal of Institutions and Economies, 1(2), 191-205. Retrieved from https:// www.researchgate.net/publication/46532791_Reconsidering_ Public-Private_Partnerships_in_ Developing_Countries

9. Jomo, K., Chowdhury, A., Sharma, K., \& Platz, D. (2016). PublicPrivate Partnerships and the 2030 Agenda for Sustainable Development: Fit for purpose? (Working Paper, 148, 28). New York, 10017,
USA. Department of Economic \& Social Affairs. Retrieved from https://sustainabledevelopment. un.org/content/documents/2288de saworkingpaper148.pdf

10. Kofanova, O., Tereshchenko, Yu., Kutsyi, R., Morhun, N., \& Gushchyn, O. (2019). Actual situation of computer crime in the credit and financial sphere of Ukraine (modern aspects). Banks and Bank Systems, 14(1), 172180. http://dx.doi.org/10.21511/ bbs.14(1).2019.15

11. Kredisov, A., \& Bilous, A. (2016). Derzhavno-pryvatne partnerstvo: vsesvitnie ta yoho vykorystannia $\mathrm{v}$ Ukraini [State-private partnership: the world experience and its use in Ukraine]. Ekonomika Ukrainy - Ukrainian Economy, 2(651), 4-16. (In Ukrainian). Retrieved from http://kaf.ep.onaft.edu.ua/ wp-content/uploads/2016/03/economica_ukr_02_2016_ukr.pdf

12. Laptiy, T. (2017). Formuvannia solidarno-rehuliatyvnoi systemy vidnosyn derzhavy ta maloho pidpryiemnytstva [Formation of solidarity-regulatory system of relations between the state and small business]. Abstract, 23. (In Ukrainian). Retrieved from http:// stu.cn.ua/media/files/pdf/dis/ aref_laptiy.pdf

13. Legislation of Ukraine. (n.d.). Retrieved from https://zakon.rada. gov.ua/laws

14. Mashchenko, M. (2018). Derzhavno-pryvatne partnerstvo yak umova invaironmentalnoi bezpeky [Public-private partnership as a precondition for ensuring environmental security]. Efektyvna Ekonomika - Efficient Economy, 12, 1-7. (In Ukrainian). http://dx.doi.org/10.32702/23072105-2018.12.81

15. Pavlova, G. (2011). Derzhavnopryvatne partnerstvo: analiz vsebichnoho dosvidu ta shliakhiv rozvytku v Ukraini [Public-Private Partnership: An Analysis of World Experience and Development Pathways in Ukraine]. Derzhava $i$ Rynok - State and Market, 130-133. (In Ukrainian). Retrieved from http://www.kbuapa.kharkov.ua/ebook/putp/2011-3/doc/3/02.pdf
16. Pavlyuk, K., \& Pavlyuk, S. (2010). Sutnist i rol derzhavno-pryvatnoho partnerstva v sotsialnoekonomichnomu rozvytku derzhavy [The essence and role of public-private partnership in the socio-economic development of the state]. Naukovi pratsi Kirovohradskoho natsionalnoho tekhnichnoho universytetu. Ekonomichni nauky - Scientific works of the Kirovohrad national technical university. Economic Sciences, 17, 10-19. (In Ukrainian). Retrieved from http://nbuv.gov.ua/UJRN/ Npkntu_e_2010_17_4

17. Renda, A., \& Schrefler, L. (2005). Public-Private Partnerships: Models and Trends in the European Union [Text]. The European Parliament, 65-67. Retrieved from http://www.europarl. europa.eu/thinktank/en/document. html? reference=IPOL-IMCO_ NT\%282006\%29369859

18. Simak, S. (2014). Svitovyi dosvid orhanizatsii derzhavno-pryvatnoho partnerstva [World experience of public-private partnership organization]. Naukovi pratsi: Derzhavne upravlinnia - Scientific works: Public Administration, 223/201(235), 88-93. (In Ukrainian). Retrieved from http:// nbuv.gov.ua/UJRN/Npchdu_2014_235_223_18

19. State Statistics Service of Ukraine. (n.d.). Retrieved from http:// ukrstat.org/en

20. The Ministry for Development of Economy, Trade and Agriculture of Ukraine. (n.d.). Retrieved from http://www.me.gov.ua

21. The Ministry of Economic Development and Trade of Ukraine. (2017). Tsili staloho rozvytku: Ukraina. Ministerstvo ekonomichnoho rozvytku i torhivli Ukrainy [Sustainable Development Goals: Ukraine. Ministry of Economic Development and Trade of Ukraine]. (In Ukrainian). Retrieved from https://menr.gov.ua/files/docs/ Національна\%20доповідь\%20 ЦСР\%20України_липень\%20 2017\%20ukr.pdf

22. The World Bank. (2015). Featured Rankings, 1990 to 2018. Retrieved from http://ppi.worldbank.org/ snapshots/rankings 
23. Transparency International (2019). Corruption perceptions index 2018. Retrieved from https:// www.transparency.org/cpi2018

24. UkraineInvest (2019)

Norvegian Ukrainian Business Forum in Oslo. Retrieved from https://ukraineinvest $\mathrm{com} /$ ? $\mathrm{s}=$ The + Norwegian-Ukrainian+Business+Forum+in+Oslo

25. Uzunov, F. (2015). Formuvannia efektyvnykh instrumentiv realizatsii derzhavno-pryvatnoho partnerstva Ukrainy [Formation of effective tools for realization of public-private partnership of Ukraine]. Aktualni problemy derzhavnoho upravlinnia - Actual problems of public administration, 1(47), 167-175. (In Ukrainian).

Retrieved from http://nbuv.gov.ua/ UJRN/apdy_2015_1_24

26. Varnavsky, V., Klymenko, A., \& Korolev, V. (2010). Gosudarstvenno-chastnoe partnerstvo: teoriya i praktika [Public-private partnership: theory and practice] (287 p.). Moscow: Higher School of Economics. (In Russian). Retrieved from https://www.twirpx. com/file/848919/

27. Yurtayeva, K. (2018). Suchasni tendentsii ekonomichnoi zlochynnosti v Ukraini [Contemporary tendencies of economical crime in Ukraine].
Visnyk Kryminolohichnoi Asotsiatsii Ukrainy - Bulletin of the Criminological Association of Ukraine, 2(19), 109-119. (In Ukrainian). Rertrieved from http://univd.edu. ua/science-issue/issue/3454

28. Zapatrina, I. (2016). Pravove rehuliuvannia ne ye osnovnoiu pereshkodoiu dlia realizatsii DPP [Legal regulation is not the main obstacle for the implementation of PPP]. Yurydychna Gazeta online - Legal Newspaper online, 49-50, 547-548. (In Ukrainian). Retrieved from http://yur-gazeta.com/interview/pravove-regulyuvannya-nee-osnovnoyu-pereshkodoyu-dlyarealizaciyi-dpp-irina-zapatrina. html 